\title{
Sedimentation Rates and Heavy Metal Concentrations in the Tidal Flats of North Vietnam
}

\author{
Nhon Dang Hoai ${ }^{1 *}$, Thanh Tran Duc ${ }^{1}$, Huy Dinh Van ${ }^{1}$, Hai Phan Son², \\ Ha Nguyen Manh ${ }^{3}$, Lan Tran Dinh ${ }^{1}$, Duan Xiaoyong ${ }^{4}$, Ve Nguyen Dac ${ }^{1,5}$
}
${ }^{1}$ Institute of Marine Environment and Resources, Vietnam Academy of Science and Technology, Hai Phong, Vietnam ${ }^{2}$ Nuclear Research Institute, Vietnam Atomic Energy Institute, Da Lat, Lam Dong Province, Vietnam
${ }^{3}$ Hanoi University of Science, Vietnam National University, Thanh Xuan, Ha Noi, Vietnam
${ }^{4}$ Qingdao Institute of Marine Geology, 62 Fuzhounan Road, Qingdao, China
${ }^{5}$ State Key Laboratory of Marine Geology, Tongji University, Shanghai, China

Received: 6 April 2018

Accepted: 21 October 2018

\begin{abstract}
Tidal flats in the north of Vietnam from Quang Ninh to Ninh Binh provinces are impacted by land-ocean interaction processes and human activity. The flats are experiencing erosion in some parts and accretion in others, as well as the accumulation of pollutants. This study examines core samples extracted from the region to systematically quantify changes in sedimentary processes and the accumulation of heavy metals. A total of 11 sediment cores were collected from the tidal flats and analyzed for ${ }^{210} \mathrm{~Pb},{ }^{226} \mathrm{Ra}$, grain size, and heavy metal content. Sedimentation rates, according to the constant rate supply model (CRS), ranged from 0.04 to $15.00 \mathrm{~cm} /$ year. There was evidence of spikes in sedimentation rates for brief episodes; however, the average ranged from 0.14 to $3.04 \mathrm{~cm} /$ year. In the north of the study area, the sedimentation rate was low, then increased to the center and the south. The concentrations of heavy metals $(\mathrm{Cu}, \mathrm{Zn}, \mathrm{Pb}, \mathrm{As}$, and $\mathrm{Cd})$ in the sediments were found to increase with time. Additionally, an increasing trend was observed from the north to the south of the study area. The concentrations of heavy metals $\mathrm{Cu}, \mathrm{Pb}$, and $\mathrm{As}$ in the sediments from the center to the south exceeded the ISQG levels.
\end{abstract}

Keywords: tidal flats; sedimentary environment; sedimentation rate; heavy metals; Vietnam

\section{Introduction}

Tidal flats, a type of coastal wetland, play an important role by providing space for socio-economic

*e-mail: nhondh@imer.ac.vn

development, various resources, and high biodiversity. Connected to the mainland, tidal flats are affected by both human activities and natural processes, which cause erosion, accumulation of pollutants, and loss of biological resources. Studying the sediments of tidal flats can provide details of natural phenomena and human activities as key factors to understand sedimentary processes and human impacts. 
Tidal flats in northern Vietnam are found in the area from Quang Ninh Province to Ninh Binh Province, where three river systems discharge into the sea. From north to south, these are the small rivers of the north, the Thai Binh River system in the center, and the Red River system in the south. Collectively, the systems include the mouths of Ka Long, Tien Yen, Ba Che, Troi, Bach Dang, Cam, Lach Tray, Van Uc, Thai Binh, Ba Lat, Ninh Co, and Day rivers (Fig. 1).

The rivers bring water and sediment from the mainland to the sea, creating changes in coastal environmental conditions and leaving relics as a record of both human impacts and natural phenomena in tidal flat sediments over time. High sedimentation rates will reduce the negative impact of rising sea levels by climate change, reduce erosion coastal area, expand tidal flats toward the sea, and increase habitat areass. High accumulation of heavy metals will impact organisms on tidal flats, and indirectly impact the human food net.

Studies have been published in the literature on sediments found in the coastal regions of northern Vietnam, helping us understand environmental conditions, such as the sedimentation rates, and accumulation of heavy metals in tidal flats [1-2]. These studies are the small areas near the Troi and Ba Lat rivers. Existing publications indicate the influence of natural processes and human activities on tidal flat environments.

However, questions remain regarding the impact of humans and nature on tidal flat environments both in the past and at present. The study area is extended to all of northern Vietnam in order to help us gather more information on the impact of human and natural activities. Analysis of sediment cores from the tidal flats for grain size, lead-210 $\left({ }^{210} \mathrm{~Pb}\right)$, radium-226 $\left({ }^{226} \mathrm{Ra}\right)$, and heavy metals over time will help answer these questions.

\section{Material and Methods}

\section{Study area Characteristics}

The study area (coastal north Vietnam) is located in the monsoon tropical climate region with two seasons a year: rainy and dry. The rainy season is from May to September and the dry season is from October to

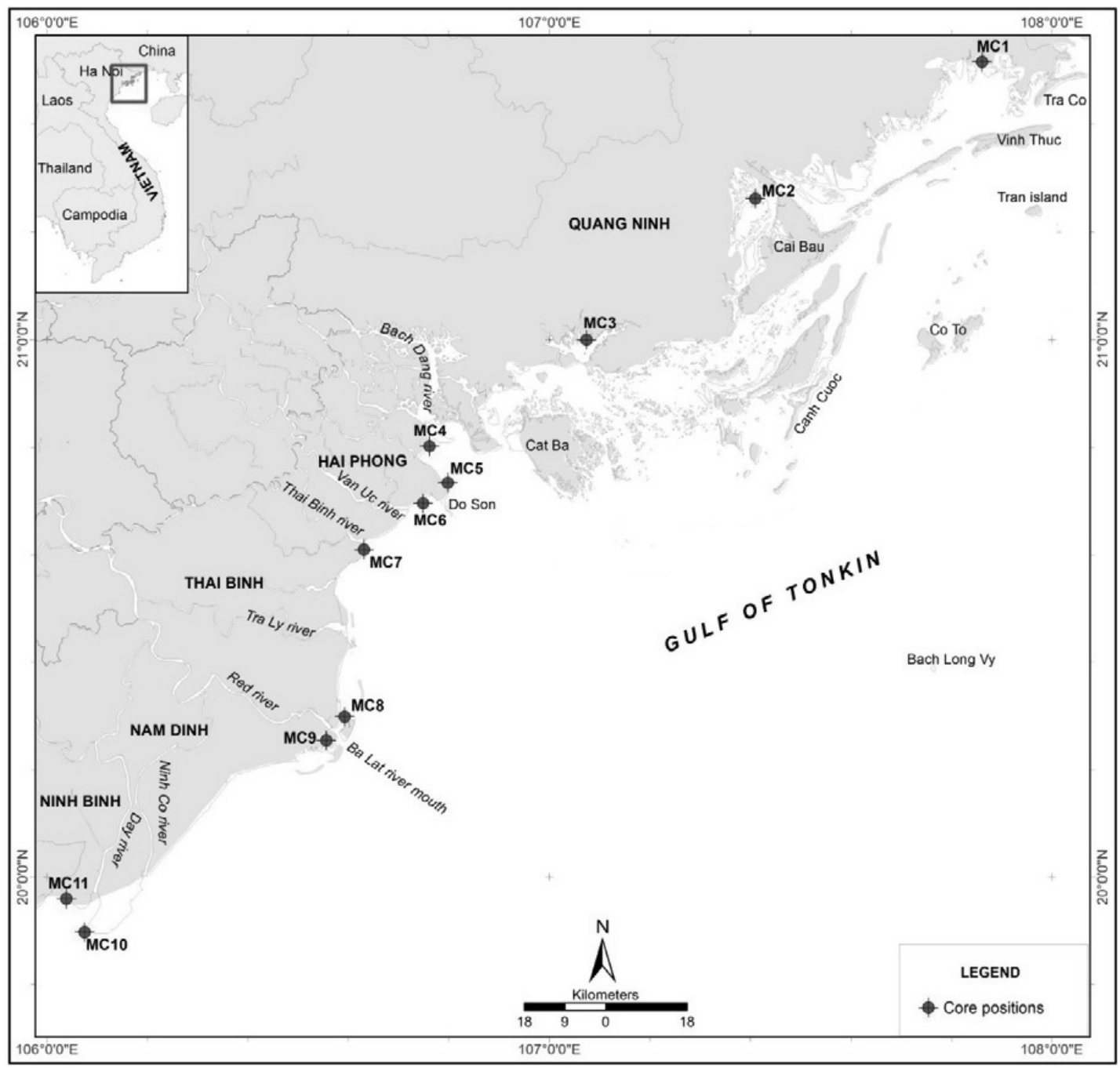

Fig. 1. Position of sediment cores on the tidal flats in north Vietnam. 
April. There is a difference of about $10^{\circ} \mathrm{C}$ between the average air temperature in the rainy and dry seasons. During the rainy season, the air temperature varies from $26-40^{\circ} \mathrm{C}$, with an average of $29^{\circ} \mathrm{C}$; during the dry season, the air temperature varies from $7-26^{\circ} \mathrm{C}$, with an average of $19^{\circ} \mathrm{C}$. The total annual rainfall is around $1800 \mathrm{~mm}$, ranging from $200-500 \mathrm{~mm}$ per month and 20-200 mm per month in the rainy and dry seasons, respectively [3].

Three river systems impact the tidal flat environments in northern Vietnam: first, the system of small rivers from the mountains in Quang Ninh Province with the mouths of the Ka Long, Tien Yen, Ba Tre, and Troi rivers; second, the Thai Binh River system in the center of the study area, with the mouths of the Bach Dang, Nam Trieu, Cam, and Van Uc rivers; and third, the Red River system with mouths of the Thai Binh, Ba Lat, Lach Giang, and Day rivers on the south side of the study area. The first river system has historically discharged 3.15 million tons of total suspended solids (TSS) per year. The second and third river systems discharged TSS of more than 84.85 million tons per year before the Hoa Binh Dam was built in 1979; after completion of the dam, the TSS dropped to 35.14 million tons per year [3].

The tide in the study area spans from macro tidal to meso tidal with a range of $0.39-4.67 \mathrm{~m}$ in the north (Cua Ong station), 0.38-4.05 $\mathrm{m}$ in the center (Hon Dau station), and $0.8-3.05 \mathrm{~m}$ (Ba Lat station) to the south of the study area. The duration of the tidal range differs in each area: in the north, the spring tide lasts longer than the neap tide; in the center, the duration of the spring tide is equal to that of the neap tide; and in the south, the neap tide lasts longer than the spring tide [4].

Along the coastal area of northern Vietnam, there are sedimentary rocks formed from the Paleozoic to the Cenozoic eras. In the Paleozoic zone, the terrigenous to marine rocks are sandstone, siltstone, claystone, and limestone, distributed from the center to the north of the study area. In the Mesozoic zone, the terrigenous rocks found on the mainland include siltstone, sandstone, claystone, and conglomerates, as well as coal mines. In the Cenozoic zone, conglomerate, gilfstone, sandstone, siltstone, and claystone are found in the north of the study area. The quaternary zone, found in the south of the study area, is made up of gravel, sand, silt, and clay originating from a mixture of marine and terrigenous sources [4].

\section{Sampling and Analysis}

Between 2009 and 2012, three campaigns were carried out to collect sediment core (MC) samples: $\mathrm{MC}$ $6(0-40 \mathrm{~cm})$ and MC $5(0-63 \mathrm{~cm})$ in April 2009; MC 8 $(0-40 \mathrm{~cm})$ and $\mathrm{MC} 11(0-50 \mathrm{~cm})$ in October 2010; and MC $1(0-90 \mathrm{~cm})$, MC $2(0-70 \mathrm{~cm})$, MC $3(0-70 \mathrm{~cm}), \mathrm{MC}$ $4(0-90 \mathrm{~cm}), \mathrm{MC} 7(0-90 \mathrm{~cm}), \mathrm{MC} 9(0-90 \mathrm{~cm})$, and $\mathrm{MC}$ $10(0-90 \mathrm{~cm})$ in March 2012 (Fig. 1). Sediment core samples were cut to the following sizes: $2 \mathrm{~cm}$ from the surface to $21 \mathrm{~cm}$ depth, $3 \mathrm{~cm}$ from $21-51 \mathrm{~cm}$ depth, and $4 \mathrm{~cm}$ from $51 \mathrm{~cm}$ to the end of the core. The sample cores were maintained at $4{ }^{\circ} \mathrm{C}$ in the field and were subsequently allowed to dry in the laboratory at $16^{\circ} \mathrm{C}$.

After removing salts and organic matter by washing with distilled water and hydrogen peroxide $\left(10 \% \mathrm{H}_{2} \mathrm{O}_{2}\right)$, the sediment grain size was analyzed using sieves for coarse grains $(>0.063 \mathrm{~mm})$ and pipettes for fine grains $(<0.063 \mathrm{~mm})$. The sediments were classified into 17 types from cobbles to pelitic muds base on mean diameter (Md) according to Lisitzin's method [5].

The total activity of ${ }^{210} \mathrm{~Pb}$ in the sediments was determined through its daughter radionuclide polonium-210 $\left({ }^{210} \mathrm{Po}\right)$ with the assumption of secular equilibrium. The sediments were digested using nitric acid $\left(\mathrm{HNO}_{3}\right)$ and concentrated hydrogen fluoride (HF). After digestion of the sample, polonium was extracted with $0.1 \%$ DDTC (diethylammonium diethyldithiocarbamate) in chloroform from $5 \mathrm{M} \mathrm{HCl}$ solution and then deposited on a silver disc. ${ }^{209} \mathrm{Po}$ was used as a tracer for calculating the yield of the whole chemical procedure. Radionuclide ${ }^{210} \mathrm{Po}$ was analyzed by an alpha spectrometer (Alpha Analyst, CANBERRA) using PIPS detectors with a $900 \mathrm{~mm}^{2}$ active area. Radionuclide ${ }^{226} \mathrm{Ra}$ in the sediments was determined directly by gamma spectrometry using a GMX high purity germanium (HPGe) detectors with $30 \%$ relative efficiency (ORTEC). ${ }^{226} \mathrm{Ra}$ was measured by the $295 \mathrm{keV}$ and $352 \mathrm{keV}$ gamma rays emitted by its daughter isotope ${ }^{214} \mathrm{~Pb}$ and by $609 \mathrm{keV}$ gamma ray emitted by bismuth-214 $\left({ }^{214} \mathrm{Bi}\right.$ ). Unsupported ${ }^{210} \mathrm{~Pb}$ (or excess ${ }^{210} \mathrm{~Pb}$ ) was calculated by subtracting ${ }^{226} \mathrm{Ra}$ from total ${ }^{210} \mathrm{~Pb}$

The constant rate supply (CRS) model was used to calculate the chronology of the sediment layers (Equation [1]). The CRS model is commonly used in calculating sedimentation rates of coastal area and estuaries:

$$
t=\frac{1}{\lambda} \ln \left(\frac{A(0)}{A(x)}\right)
$$

...where $t$ is time in years; $\lambda$ is a constant $=0.031 ; A(0)$ is the ${ }^{210} \mathrm{~Pb}_{\text {excess }}$ in the whole sediment core; and $A(x)$ is ${ }^{210} \mathrm{~Pb}_{\text {excess }}$ in sediment core at depth $x$.

Inductively coupled plasma mass spectrometry (ICP-MS) was employed for the quantification of heavy metals (copper $[\mathrm{Cu}]$, lead $[\mathrm{Pb}]$, zinc $[\mathrm{Zn}]$, arsenic [As], cadmium [Cd]), and X-ray fluorescence (XRF) was used for evaluating the level of aluminum (Al). After drying the sediments, $0.5 \mathrm{~g}$ was removed and extracted using $10 \mathrm{ml}$ of $8 \mathrm{M}$ of $\mathrm{HNO}_{3}$ and $3 \mathrm{ml}$ of $30 \% \mathrm{H}_{2} \mathrm{O}_{2}$ under reflux at $95^{\circ} \mathrm{C}$ for 15 minutes. Subsequently, samples were cooled and $5 \mathrm{ml}$ of $16 \mathrm{M} \mathrm{HNO}_{3}$ was added; the samples were then kept at $95^{\circ} \mathrm{C}$ for 2 hours, cooled, and filtered using $0.45-\mu \mathrm{m}$ filter paper (Whatman Cellulose Filter Paper). Finally, samples were diluted to $100 \mathrm{ml}$ and analyzed by ICP-MS (Elan 9000 Perkin Elmer). 
Table 1. Geo-accumulation index, enrichment factor, and sediment quality.

\begin{tabular}{|c|c|c|c|c|c|}
\hline \multicolumn{3}{|c|}{ Geoaccumulation index } & \multicolumn{3}{|c|}{ Enrichment factor } \\
\hline Class & Value & Classification & Level & Value & Categorization \\
\hline 0 & $<0$ & Unpolluted & I & $<1$ & No enrichment \\
\hline 1 & $0-1$ & Unpolluted to moderated polluted & II & $1-3$ & Minor enrichment \\
\hline 2 & $1-2$ & moderately polluted & III & $3-5$ & Moderate enrichment \\
\hline 3 & $2-3$ & Moderately to strongly polluted & IV & $5-10$ & Moderately severe enrichment \\
\hline 4 & $3-4$ & Strongly polluted & V & $10-25$ & Severe enrichment \\
\hline 5 & $4-5$ & Strongly to extremely polluted & VI & $25-50$ & Very severe enrichment \\
\hline 6 & $>5$ & Extremely polluted & VII & $>50$ & Extremely severe enrichment \\
\hline
\end{tabular}

All chemicals used were of analytical grade. For the QA/QC of the analysis processes, certified reference material samples (PACS-2-National Research Council of Canada) were tested once every 20 samples; the recovery of heavy metals in the certified reference material ranged from $88-110 \%$. For determining the Al content, samples were ground under $0.063 \mathrm{~mm}$ and analyzed using X-ray fluorescence (Shimadzu XRF$1800)$ with a $4-\mathrm{kW}$ thin-window $\mathrm{X}$-ray tube $(40 \mathrm{kV}$ voltage and current intensity of $95 \mathrm{~mA}$ ).

In addition to comparing against the Canadian sediment quality guidelines [6], heavy metal concentrations in the sediments were used to track changes in the cores via the geo-accumulation index $\left(\mathrm{I}_{\mathrm{Geo}}\right)$ [7] and the enrichment factor (EF) [8]. The $\mathrm{I}_{\mathrm{Geo}}$ is calculated using Equation (2) and the EF is calculated using Equation (3). They were then divided into six classes and six categories based on the $\mathrm{I}_{\mathrm{Geo}}$ and the EF (Table 1).

The geo-accumulation index is:

$$
\mathrm{I}_{\mathrm{Geo}}=\log 2(\mathrm{Cn} / 1.5 \mathrm{Bn})
$$

...where $\mathrm{I}_{\mathrm{Geo}}$ is the geo-accumulation index; $\log 2$ is $\log$ base 2; $\mathrm{Cn}$ is the metal concentration; and $\mathrm{Bn}$ is the average concentration of metal in the Earth's crust.

The EF is:

$$
\mathrm{EF}=\left[(\mathrm{E} / \mathrm{Al})_{\text {sample }} /(\mathrm{E} / \mathrm{Al})_{\text {background }}\right]
$$

...where $(\mathrm{E} / \mathrm{Al})_{\text {sample }}$ is the ratio of the metal concentration in the sample to the aluminum concentration in the sample; and $(\mathrm{E} / \mathrm{Al})_{\text {background }}$ is the ratio of the average metal concentration in the Earth's crust to the average aluminum concentration in the crust.

For $\mathrm{Bn}$, the concentrations in the Earth's crust of Al, $\mathrm{Cu}, \mathrm{Pb}, \mathrm{Zn}, \mathrm{As}$, and $\mathrm{Cd}$ are reported by Rudnick and Gao [9] to be $81259 \mathrm{mg} / \mathrm{kg}, 28.00 \mathrm{mg} / \mathrm{kg}, 17.00 \mathrm{mg} / \mathrm{kg}$, $67.00 \mathrm{mg} / \mathrm{kg}, 4.80 \mathrm{mg} / \mathrm{kg}$, and $0.09 \mathrm{mg} / \mathrm{kg}$, respectively. For each core, the reported metal concentration is the average from all samples in the core.
The values average, standard deviation (SD), correlation (R), principal component analysis (PCA). All statistical analyses were performed using Origin Pro 9.1 (OriginLab).

\section{Results}

\section{Distribution of Grain Size in Tidal Flats}

From Quang Ninh to Ninh Binh, sediments in the tidal flats are composed of coarse sand, medium sand, fine sand, coarse aleurites, fine-aleurite muds, and aluretic-pelitic muds. Coarse, medium, and fine sands were found only in the north of the study area and most of them were moderately to poorly sorted (in cores $\mathrm{MC}$ 1, MC 2, and MC 3). Fine sediments dominated the center (in cores MC 4, MC 5) and the south (in cores MC 6-11) of the study area and most of them were poorly to moderately sorted (Table 2).

Table 2 and Fig. 2 show the distribution parameters of the sediments, including the mean diameter $(\mathrm{Md})$ and sorting coefficient $\left(\mathrm{S}_{0}\right)$. The mean diameters of the sediments in the cores changed with depth, reflecting the change in the sedimentary environmental conditions over time. Based on the $\mathrm{Md}$ and $\mathrm{S}_{0}$ of the sediments, the sedimentary environment on the tidal flats can be divided into two periods that were controlled by processes of erosion and accretion. Erosion processes were seen in the north and the south areas at $\mathrm{MC} 11$ at a depth of $27-50 \mathrm{~cm}$, at $\mathrm{MC} 10$ erosion and accretion were alternating from $22-90 \mathrm{~cm}$, at MC 8 at a depth of $33-40 \mathrm{~cm}$, at MC 3 at a depth of $20-66 \mathrm{~cm}$, and at $\mathrm{MC} 1$ at $15-90 \mathrm{~cm}$ depth where the $\mathrm{Md}$ in the cores changed from coarse aleurites $(0.05 \mathrm{~mm}<\mathrm{Md}<0.10 \mathrm{~mm})$ to coarse sands $(0.5 \mathrm{~mm}<\mathrm{Md}<1$ $\mathrm{mm})$. Accretion processes were detected in all cores near the surface: at MC 11 at a depth of $0-27 \mathrm{~cm}$; at $\mathrm{MC}$ 10 from $0-22 \mathrm{~cm}$; at MC 8 at depth of $0-27 \mathrm{~cm}$; at $\mathrm{MC}$ 6, MC 7, MC 5, and MC 4 at all depths; and at MC 1 and $\mathrm{MC} 3$ at a depth of $0-20 \mathrm{~cm}$. The sorting coefficient of the sediment is higher in the accretion layers than in the erosion layers. 


\begin{tabular}{|c|c|c|c|c|c|c|c|c|c|c|c|c|c|}
\hline 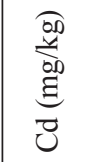 & $\begin{array}{l}= \\
0 \\
0 \\
\text { t. } \\
0 \\
0\end{array}$ & 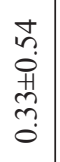 & $\begin{array}{l}5 \\
\text { 0. } \\
\text { in } \\
\text { : } \\
0\end{array}$ & & 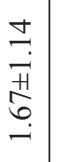 & $\begin{array}{l}8 \\
0 \\
\dot{+} \\
\stackrel{+}{+} \\
\dot{0} \\
0\end{array}$ & $\begin{array}{l}n \\
0 \\
0 \\
0 \\
m \\
0 \\
0\end{array}$ & $\begin{array}{c}= \\
\overrightarrow{0} \\
\stackrel{+}{+} \\
\stackrel{+}{0} \\
\stackrel{0}{0}\end{array}$ & ' & 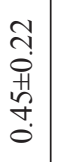 & 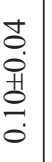 & $\tilde{0}$ & $\stackrel{\sim}{\sim}$ \\
\hline$<\stackrel{80}{b 0}$ & 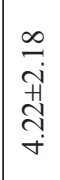 & $\begin{array}{c}\overrightarrow{\vec{T}} \\
\vec{H} \\
\overrightarrow{0} \\
\overrightarrow{0}\end{array}$ & $\begin{array}{l}\infty \\
\vec{i} \\
\stackrel{\infty}{H} \\
\stackrel{0}{\circ} \\
\dot{+}\end{array}$ & & 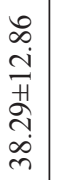 & 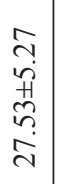 & $\begin{array}{l}\dot{8} \\
\dot{+} \\
\dot{1} \\
\infty \\
\dot{d} \\
m\end{array}$ & 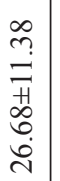 & & 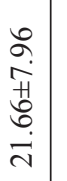 & $\begin{array}{c}\tilde{N} \\
\underset{N}{H} \\
\stackrel{H}{r} \\
\end{array}$ & 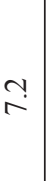 & 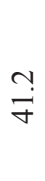 \\
\hline & $\mid \begin{array}{c}2 \\
\tilde{m} \\
\dot{ \pm} \\
\dot{H} \\
\dot{0} \\
\dot{m} \\
\dot{m}\end{array}$ & 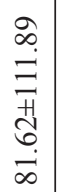 & $\begin{array}{l}\hat{m} \\
\vec{z} \\
0 \\
\infty \\
n \\
m\end{array}$ & & 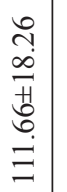 & 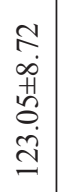 & 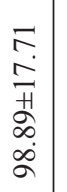 & 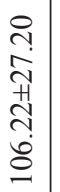 & & 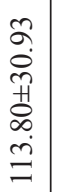 & 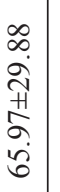 & $\stackrel{\unlhd}{\beth}$ & $\vec{\sim}$ \\
\hline $\overrightarrow{2} \stackrel{\vec{m}}{a}$ & $\mid \begin{array}{l}\infty \\
2 \\
0 \\
0 \\
0 \\
\hat{n} \\
2 \\
-\end{array}$ & $\begin{array}{l}\hat{\sigma} \\
\hat{\sim} \\
\frac{\vec{H}}{\sim} \\
\ddot{\lambda}\end{array}$ & $\begin{array}{l}8 \\
\dot{+} \\
+ \\
\dot{H} \\
o \\
\text { i } \\
\end{array}$ & & 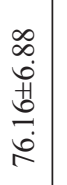 & 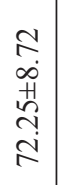 & 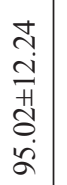 & 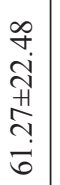 & & $\begin{array}{l}\stackrel{0}{2} \\
\infty \\
\frac{1}{H} \\
\vec{\nabla} \\
2 \\
2\end{array}$ & $\begin{array}{l}\stackrel{m}{f} \\
\overrightarrow{\vec{T}} \\
\vec{H} \\
\overrightarrow{0} \\
\dot{D} \\
\dot{\sim}\end{array}$ & $\begin{array}{l}\text { Na } \\
\stackrel{n}{n}\end{array}$ & $\Xi$ \\
\hline 己 & $\mid \begin{array}{c}\infty \\
\infty \\
\dot{+} \\
\stackrel{+}{\sim} \\
\dot{n}\end{array}$ & $\begin{array}{c}\mathbf{c} \\
\tilde{N} \\
+ \\
\infty \\
\infty\end{array}$ & $\begin{array}{l}\infty \\
\infty \\
i \\
\text { H } \\
\infty \\
\infty\end{array}$ & & 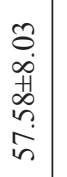 & $\begin{array}{l}0 \\
+ \\
\infty \\
0 \\
H \\
0 \\
\dot{0} \\
\infty\end{array}$ & 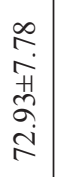 & 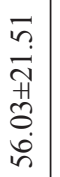 & ' & 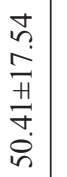 & 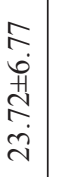 & $\underset{\infty}{\infty}$ & $\stackrel{\infty}{0}$ \\
\hline
\end{tabular}

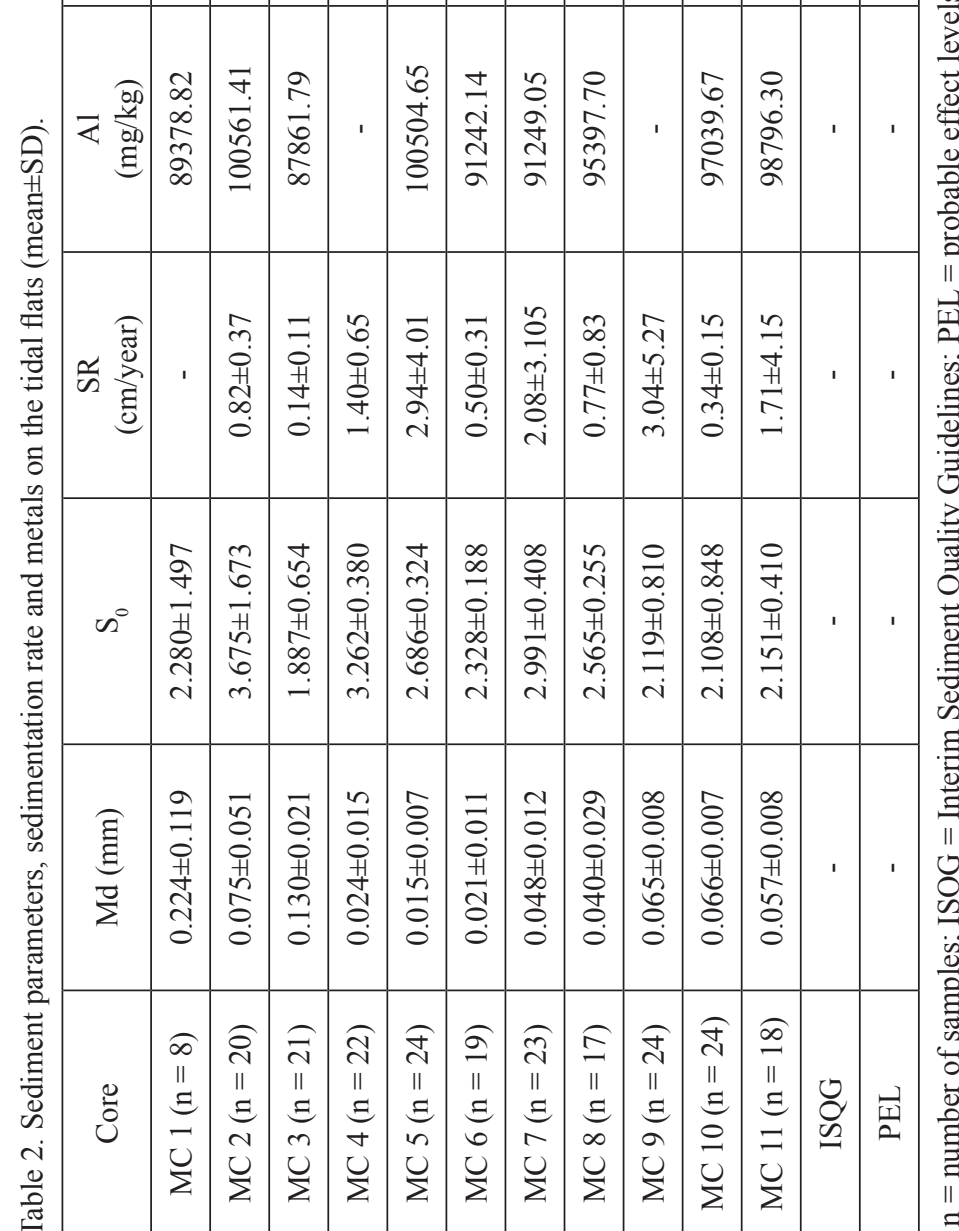



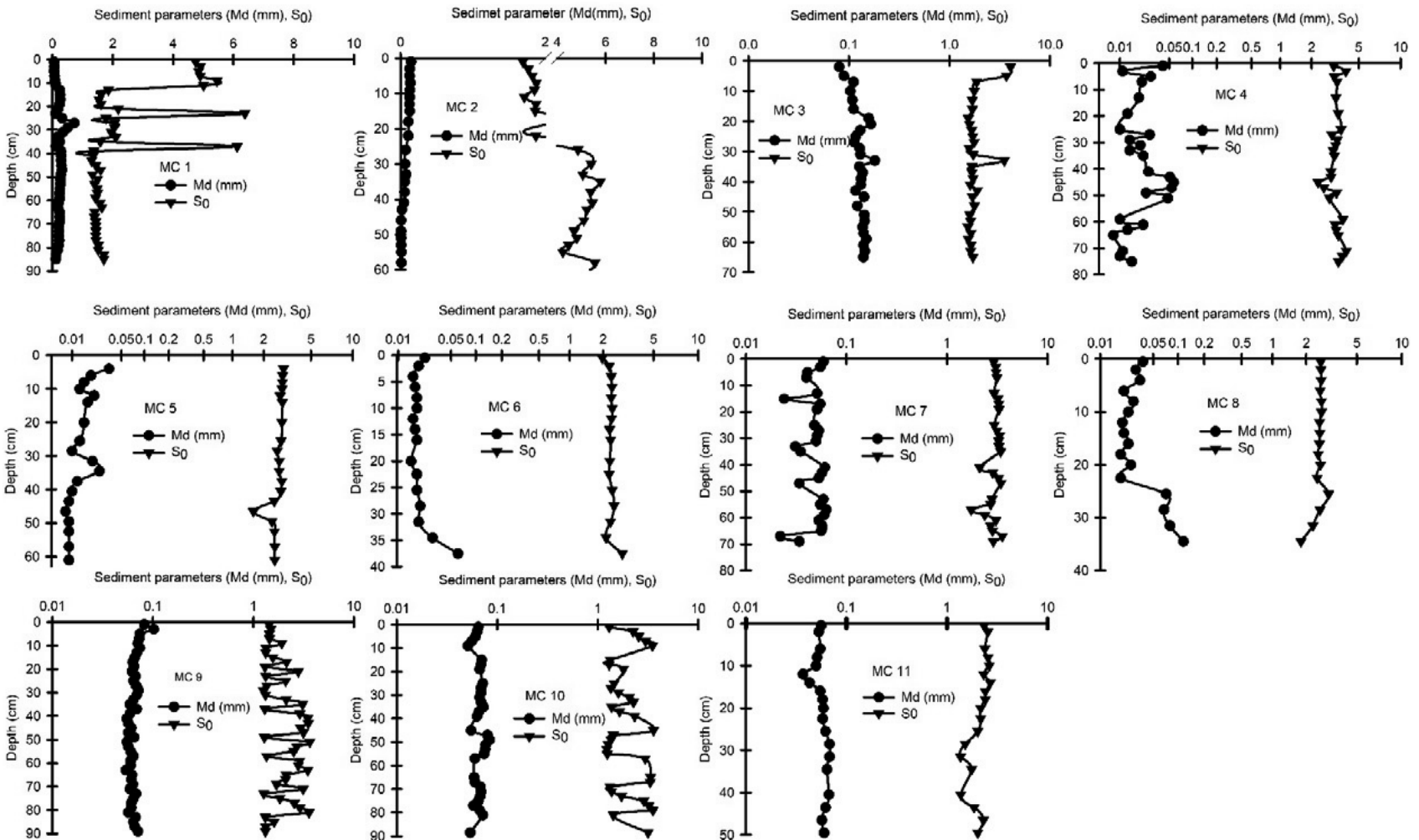

Fig. 2. Distribution of sediment parameters on tidal flats.
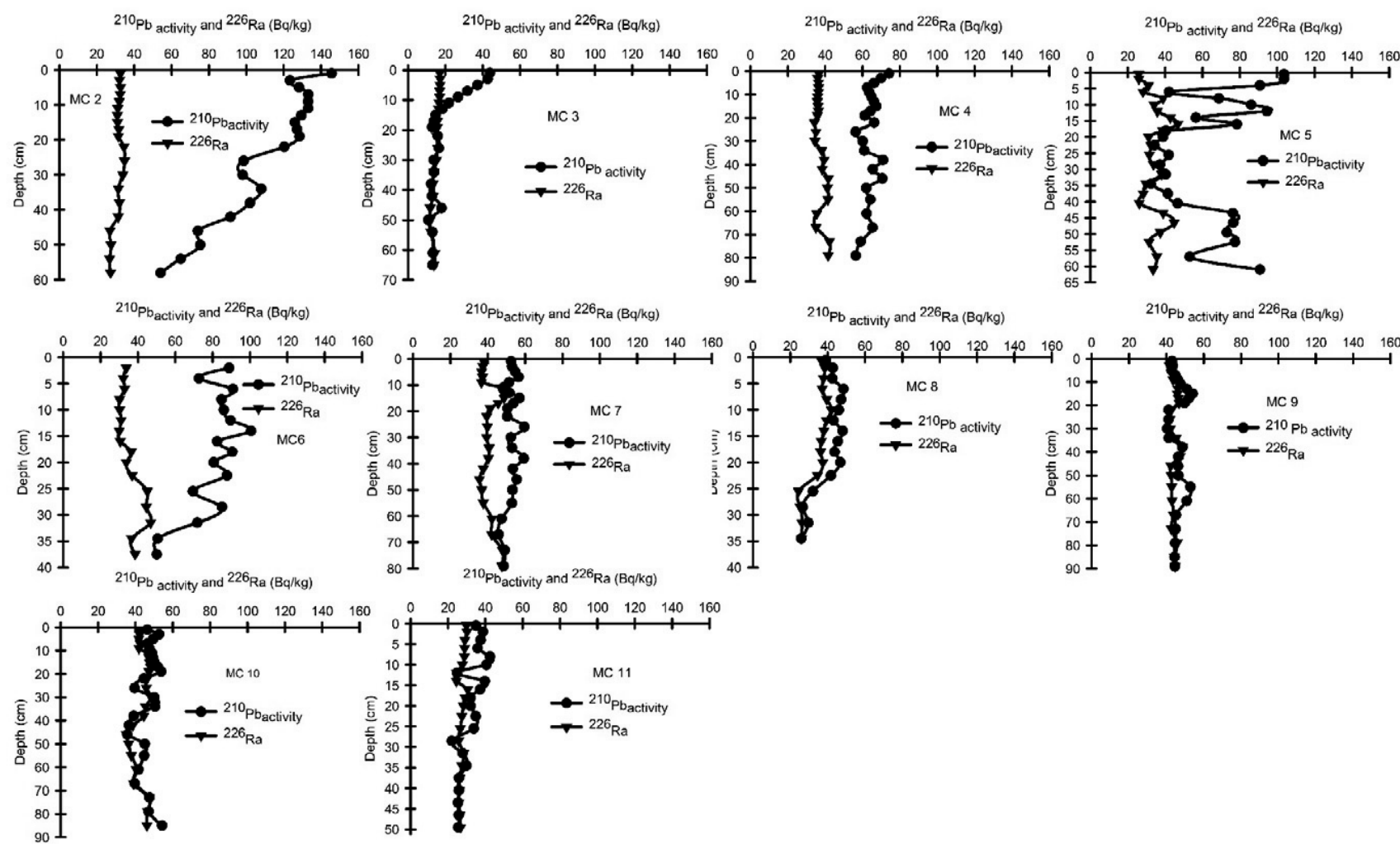

Fig. 3. Distribution of ${ }^{210} \mathrm{~Pb}$ and ${ }^{226} \mathrm{Ra}$ in sediment cores on tidal flats. 


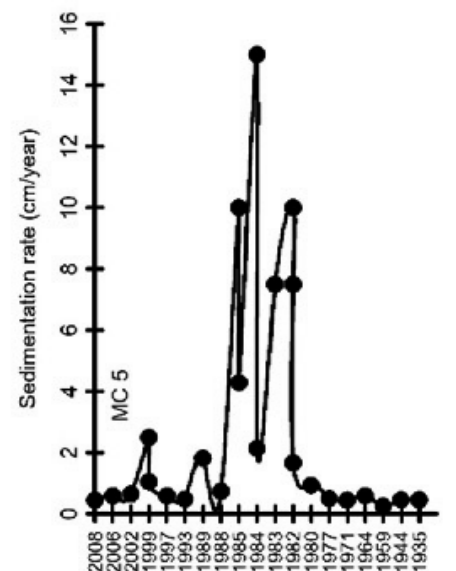

suea $ᄉ$
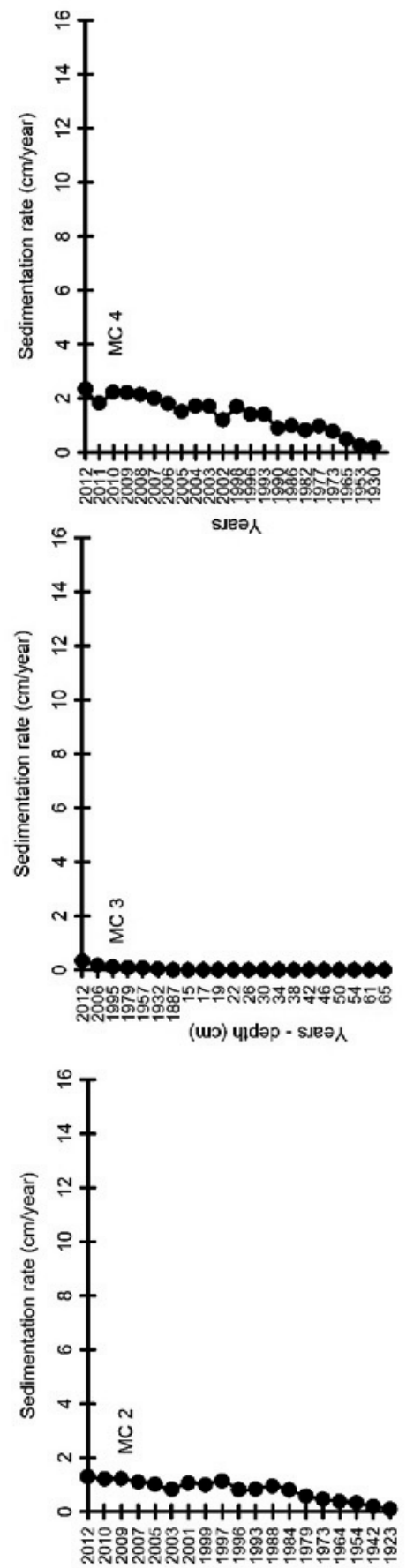

siea人

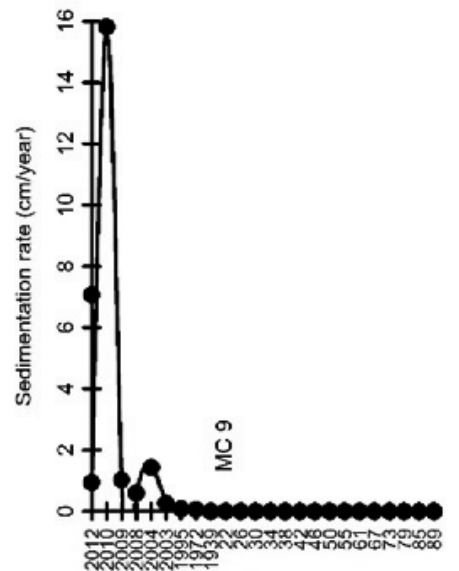

(uว) undap-sjeer
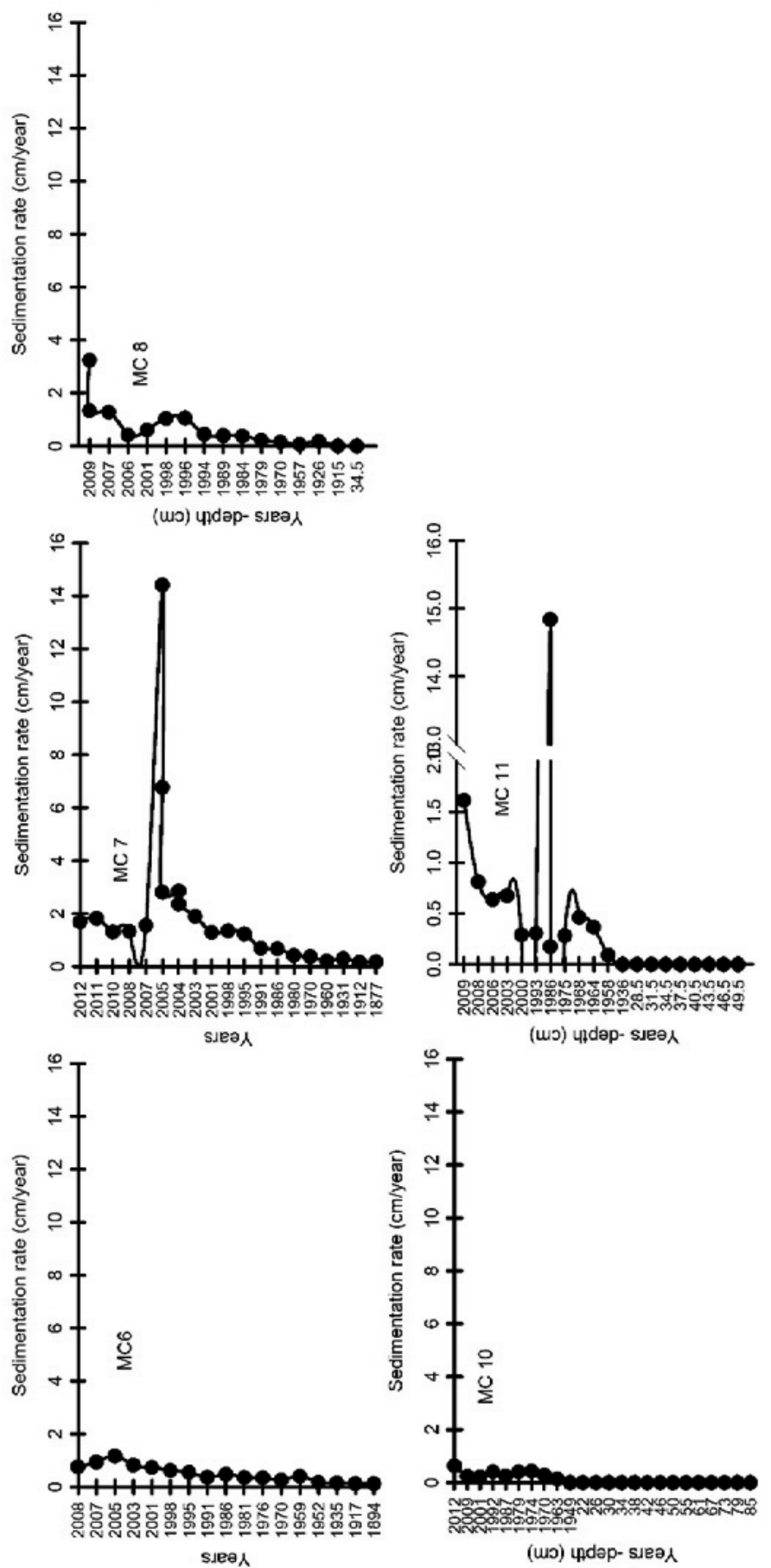

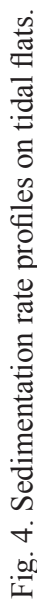



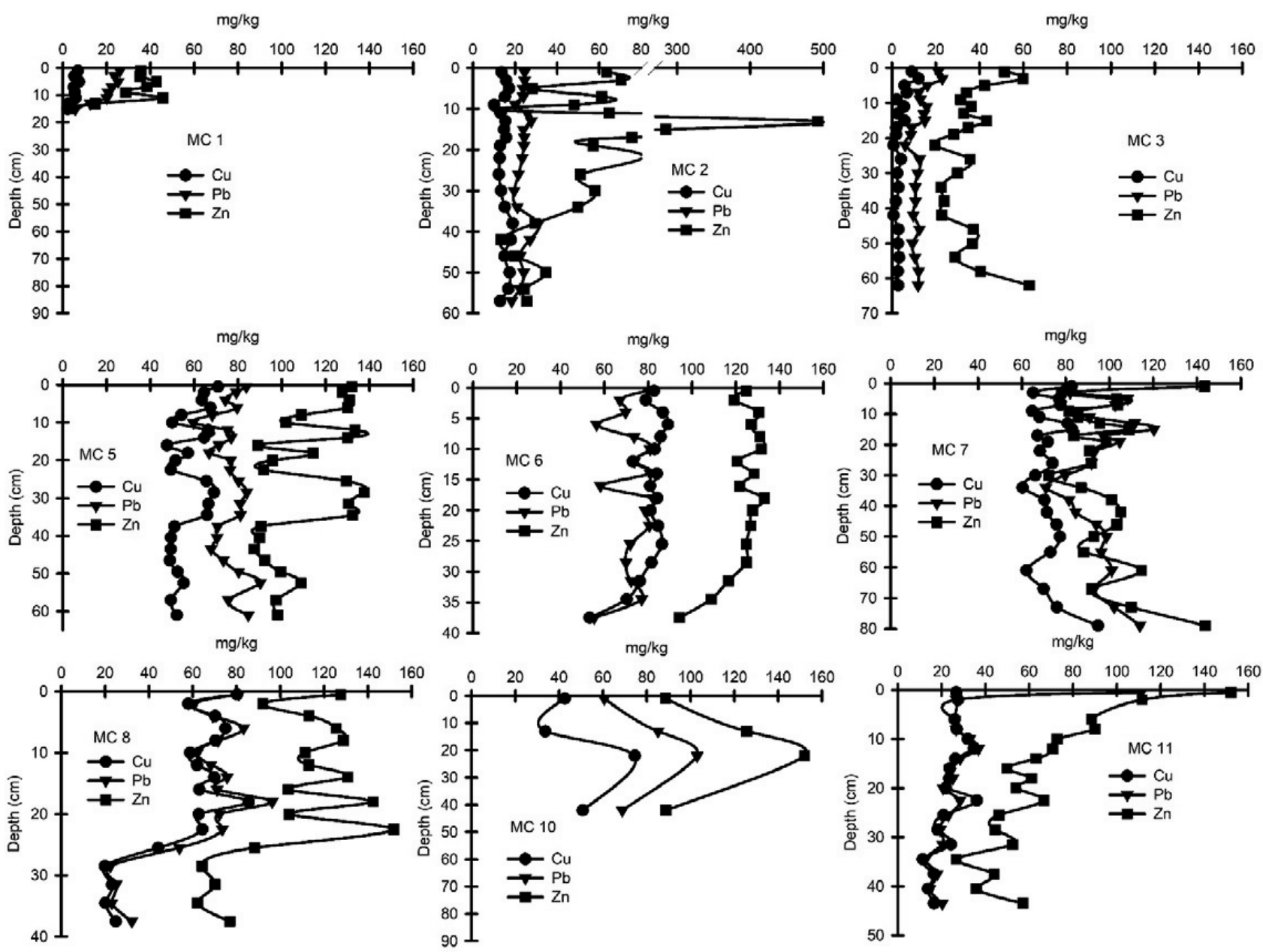

Fig. 5. Distribution of copper, lead, and zinc in sediment cores on tidal flats.

Distribution of ${ }^{210} \mathrm{~Pb}$ and ${ }^{226} \mathrm{Ra}$ and Sedimentation Rate on Tidal Flats

The ${ }^{210} \mathrm{~Pb}$ and ${ }^{226} \mathrm{Ra}$ distributions in the sediment cores can help track environmental changes. They are indicators of erosion or accretion processes. When the content of ${ }^{226} \mathrm{Ra}$ in the sediment is higher than that of ${ }^{210} \mathrm{~Pb}$, there is no deposition. On the other hand, if the content of ${ }^{210} \mathrm{~Pb}$ in the sediment is higher than that of ${ }^{226} \mathrm{Ra}$, accretion has taken place. On the tidal flats in northern Vietnam, both cases were observed.

In sediment cores MC 2, MC 4, MC 5, MC 6, and MC 7, the content of ${ }^{210} \mathrm{~Pb}_{\text {activity }}$ is higher than that of ${ }^{226} \mathrm{Ra}$ in all layers, indicating that in these areas accretion has taken place over the entire duration (Fig. 3). In sediment cores MC 3, MC 8, MC 9, MC 10, and MC 11, two phases can be observed, including the first accretion phase with the ${ }^{210} \mathrm{~Pb}_{\text {activity }}$ content in the sediment higher than that of ${ }^{226} \mathrm{Ra}$, and the later second erosion phase with the ${ }^{226} \mathrm{Ra}$ content in sediment higher than that of ${ }^{210} \mathrm{~Pb}_{\text {activity }}$ (Fig. 3).

Using the CRS model, the sedimentation rates (SR) on tidal flats changed over time in different areas. They were low in MC 3 and MC 10 (Fig. 4), and high in $\mathrm{MC} 2, \mathrm{MC} 4, \mathrm{MC} 5, \mathrm{MC}$ 7, $\mathrm{MC}$ 9, and $\mathrm{MC} 11$
(Table 2 and Fig. 4). On the tidal flats, both accretion and erosion were found at MC 11, MC10, MC 9, and MC 8. The sedimentation rate is closely related to the mean diameter $(\mathrm{Md})$ of the sediment. The higher the sedimentation rate, the more fine sediment there is. The low sedimentation rate is more closely of coarse sediment. In the three sedimentary environments (embayment, estuary, delta), a high sedimentation rate was recorded in the estuarine and deltaic tidal flat, a low sedimentation rate in embayment tidal flat. In Table 2, at MC 5, MC 7, MC 9, and MC11 the standard deviation (SD) of the sedimentation rates are a cause of changing of sedimentary environments (Fig. 4).

\section{Distribution of Metals on Tidal Flats}

The levels of $\mathrm{Al}, \mathrm{Cu}, \mathrm{Pb}, \mathrm{Zn}, \mathrm{As}$, and $\mathrm{Cd}$ in the sediment cores were analyzed. The Al concentration was determined only for the top layer $(0-2 \mathrm{~cm})$ of each core (Table 2); concentrations of other heavy metals were measured along the full depth of the cores (Table 2).

The concentration of $\mathrm{Al}$ ranges from 87861.79 to $100561.41 \mathrm{mg} / \mathrm{kg}$ dry weight. The high concentrations were found in the MC 2 and MC 5 cores. The low 

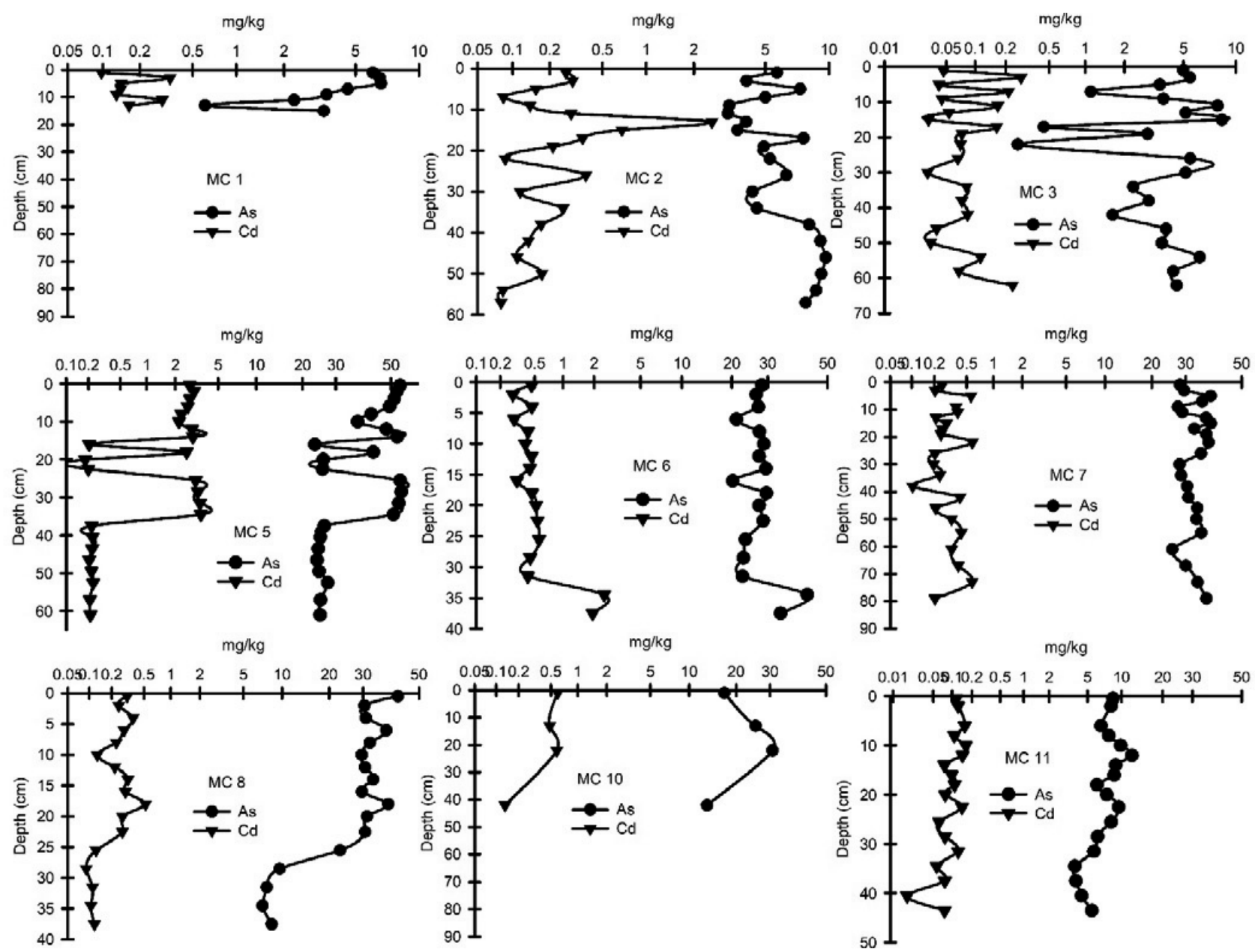

Fig. 6. Distribution of arsenic and cadmium in sediment cores on tidal flats.

concentrations of $\mathrm{Al}$ were found in the north of the study area (MC1, MC3), while the highest were found in the center (MC 5); the south of the study area (MC 6-MC 11) presented mid-level concentrations.

High concentrations of heavy metals $\mathrm{As}, \mathrm{Cu}, \mathrm{Pb}$, and $\mathrm{Zn}$ were found in $\mathrm{MC} 5, \mathrm{MC} 6, \mathrm{MC} 7, \mathrm{MC}$ 8, and MC 10 (Table 2) from the center to south. In the cores from MC $1, \mathrm{MC} 2$, and $\mathrm{MC} 3$, in the north of the study area, the lowest heavy metal concentrations were recorded. The center of the study area exhibited the highest heavy metal concentrations. In the south, heavy metal concentrations were higher than those in the north. Some heavy metal concentrations in the sediment cores have increased in recent years (i.e., in MC 5, MC 8, and MC 2 with metals $\mathrm{Cu}, \mathrm{Pb}, \mathrm{As}, \mathrm{Zn}$, and $\mathrm{Cd}$ ).

Copper in the sediments ranges from low to high concentrations. The high concentration was found in the cores from MC 5 and $\mathrm{MC}$ 6. The copper concentration in most of the $\mathrm{MC} 5-\mathrm{MC} 11$ cores are higher than Interim Sediment Quality Guidelines (ISQG) levels but lower than the Probable Effect Level (PEL). In the cores from MC 1-MC 3, the copper concentrations were below ISQG level (Table 2, Fig. 5).
The lead concentration was above the ISQG level in $\mathrm{MC} 5, \mathrm{MC} 6, \mathrm{MC} 7, \mathrm{MC} 8$, and $\mathrm{MC} 10$ cores, but none of the cores had lead concentrations higher than the PEL. High concentrations of lead were found in the south and center of the study area. Only in MC 1, MC 2, and MC 3 (i.e., the north area) were they lower than the ISQG level (Table 2, Fig. 5).

The high of zinc concentration was observed in the sediment at MC 5, MC 6, and MC 10. At select locations on the tidal flats (MC 8, MC 11, MC 3 and $M C$ 2), the concentration of zinc in the sediment increased recently. The low of zinc concentration was found at MC 1 and MC 3 (Table 2, Fig. 5).

Arsenic was found at high concentration in the sediments: up to five times higher than the ISQG level in MC 5 to MC 11 (in the south and center of the study area). Although the arsenic concentration was higher than the ISQG level, the average concentration of arsenic is lower than the PEL. In the $\mathrm{MC} 1, \mathrm{MC} 2$, and MC 3 cores, the arsenic concentration was lower than the ISQG level (Table 2, Fig. 6).

The concentration of cadmium was below the ISQG level in most of the cores, above the ISQG level only in MC 5 core, but still lower than the PEL. A trend of cadmium concentration increasing with time 
Table 3. Geo-accumulation index and enrichment factor of sediment on the tidal flats.

\begin{tabular}{|c|c|c|c|c|c|c|c|c|c|c|}
\hline & Metal & MC 1 & MC 2 & MC 3 & MC 5 & MC 6 & MC 7 & MC 8 & MC 10 & MC 11 \\
\hline \multirow{5}{*}{$\mathrm{I}_{\mathrm{Geo}}$} & $\mathrm{Cu}$ & -3.0 & -1.5 & -3.4 & 0.5 & 0.9 & 0.8 & 0.4 & 0.3 & -0.8 \\
\hline & $\mathrm{Pb}$ & -0.4 & -0.1 & -1.0 & 1.6 & 1.5 & 1.9 & 1.3 & 1.6 & 0.2 \\
\hline & $\mathrm{Zn}$ & -1.7 & -0.3 & -1.5 & 0.2 & 0.3 & 0.0 & 0.1 & 0.2 & -0.6 \\
\hline & As & -0.8 & -0.2 & -0.8 & 2.4 & 1.9 & 2.2 & 1.9 & 1.6 & 0.0 \\
\hline & $\mathrm{Cd}$ & 0.5 & 1.3 & -0.5 & 3.6 & 2.2 & 1.2 & 0.8 & 1.7 & -0.4 \\
\hline \multicolumn{2}{|c|}{ Classification } & $0 ; 1$ & $0 ; 1 ; 2$ & 0 & $1 ; 2 ; 3 ; 4$ & $1 ; 2 ; 3$ & $1 ; 2 ; 3$ & $1 ; 2$ & $1 ; 2$ & $0 ; 1$ \\
\hline \multirow{5}{*}{$\mathrm{EF}$} & $\mathrm{Cu}$ & 0.2 & 0.4 & 0.1 & 1.7 & 2.5 & 2.3 & 1.7 & 1.5 & 0.7 \\
\hline & $\mathrm{Pb}$ & 1.0 & 1.1 & 0.7 & 3.6 & 3.8 & 5.0 & 3.1 & 3.9 & 1.4 \\
\hline & $\mathrm{Zn}$ & 0.4 & 1.0 & 0.5 & 1.3 & 1.6 & 1.3 & 1.4 & 1.4 & 0.8 \\
\hline & As & 0.8 & 1.0 & 0.8 & 6.5 & 5.1 & 6.1 & 4.7 & 3.8 & 1.3 \\
\hline & $\mathrm{Cd}$ & 1.9 & 3.0 & 1.0 & 15.0 & 6.3 & 3.1 & 2.2 & 4.2 & 0.9 \\
\hline \multicolumn{2}{|c|}{ Categorization } & I; II & I; II & I & II; IV; V & II; III; IV & II; III; IV & II; III & II; III & I; II \\
\hline
\end{tabular}

$\mathrm{I}_{\mathrm{Geo}}=$ geo-accumulation index; $\mathrm{EF}=$ enrichment factor

was observed in the cores from MC 10, MC 11, MC 8, $\mathrm{MC}$ 5, and $\mathrm{MC}$ 2. The remaining cores from MC 1, MC 3, MC 6, and MC 7 did not show clear trends (Table 2, Fig. 6).

In summary, high concentrations of the heavy metals $\mathrm{Cu}, \mathrm{Pb}$, and $\mathrm{As}$ were found. Most of them are higher than ISQG levels from the center to the south of study area.

\section{Enrichment Factors and Geo-Accumulation}

The $\mathrm{I}_{\mathrm{Geo}}$ of heavy metals in the area ranges from -3.4-3.6; the values can be categorized as: unpolluted (0.0-1.0), moderate (1.0-3.0), and strongly polluted (3.0-4.0). In tidal flats, MC 5, MC 6, and MC 7 cores (Table 3), ranged from unpolluted to strongly polluted, particularly with $\mathrm{Cd}, \mathrm{As}, \mathrm{Cu}$, and $\mathrm{Pb}$. Cores from $\mathrm{MC} 8$ and $\mathrm{MC} 10$ showed that the environment was moderately polluted with $\mathrm{Pb}, \mathrm{As}$, and $\mathrm{Cd}$. The cores from $\mathrm{MC} 1$, $\mathrm{MC} 2, \mathrm{MC} 3$, and MC 11 were unpolluted with $\mathrm{As}, \mathrm{Pb}$, and $\mathrm{Zn}$, and unpolluted to moderately polluted with $\mathrm{Cd}$ and $\mathrm{Pb}$ (Table 3).

The EF for the heavy metals were in the range of 0.1-15.0, from no enrichment to severe enrichment (Table 3). A high EF was found in the cores from $\mathrm{MC}$ 5, $\mathrm{MC}$ 6, and $\mathrm{MC} 7$ for $\mathrm{As}, \mathrm{Cd}$, and $\mathrm{Pb}$, respectively, showing moderately severe to severe enrichment. In the cores from MC 8 and MC 10, the environment was moderately enriched with $\mathrm{As}, \mathrm{Cd}$, and $\mathrm{Pb}$, and minor enrichment was observed for $\mathrm{Cu}$ and $\mathrm{Zn}$. The low EFs were found at MC 1, MC 2, MC 3, and $\mathrm{MC} 11$, ranging from 0.1 to 3.0, respectively, indicating no enrichment to minor enrichment, with only $\mathrm{Pb}, \mathrm{As}$, and $\mathrm{Cd}$ exhibiting $\mathrm{EFs}>1$ (minor enrichment).

\section{Discussion}

Most sediments on tidal flats are poor $\left(\mathrm{S}_{0}>2.2\right)$ to medium (1.58-2.2) in sorting, with coarse sediments in the north and fine sediments from the center to the south, high sedimentation rates are closely related to sediment supplies: in the north of the study area, where the MC 2 and MC 3 cores were collected with low sedimentation rates, the total suspended solids (TSS) from the small rivers supply 3.15 million tons per year; while in the south and the center of the study area, where cores MC 4 to MC 11 were obtained, sedimentation rate was high and the TSS from the rivers of the Red River and the Thai Binh River systems to the coastal area was 84.85 million tons per year before construction of the Hoa Binh Dam and around 35.14 million tons per year afterwards [3].

Sedimentation rates in the cores taken from the tidal flats clearly reflect changes in the sedimentary environment resulting from human activities and natural processes. At MC 5, the sedimentation rate increased very quickly between 1982 and 1985 (Fig. 2), and the mean diameter (Md) of the sediment at this stage is higher than in previous and later stages. In the coastal area of Hai Phong, the Dinh Vu Dam was built in 1979-1981, transforming Dinh Vu Island to a peninsula and changing the direction of the Cam River; subsequently, the sedimentation rate changed rapidly in a short period of time, then re-stabilized [10]. At MC 7 during 2005-2006, MC 9 during 2009-2010, and MC 11 during 1968-1971 and 1986-1987, as a result of storms and floods in mainland northern Vietnam in 1971, 1986, 2006, 2008, and 2010 causing heavy rain and floods, the rivers brought huge amounts of material to coastal areas [11], and sedimentation rates in tidal 
Table 4. Correlation matrix of sediment parameters.

\begin{tabular}{|c|c|c|c|c|c|c|c|}
\hline & $\mathrm{Al}$ & $\mathrm{Cu}$ & $\mathrm{Pb}$ & $\mathrm{Zn}$ & $\mathrm{Cd}$ & $\mathrm{As}$ & $\mathrm{Md}$ \\
\hline $\mathrm{Al}$ & 1.00 & & & & & & \\
\hline $\mathrm{Cu}$ & 0.13 & 1.00 & & & & & \\
\hline $\mathrm{Pb}$ & 0.22 & 0.94 & 1.00 & & & & \\
\hline $\mathrm{Zn}$ & 0.50 & 0.90 & 0.86 & 1.00 & & & \\
\hline $\mathrm{Cd}$ & 0.47 & 0.46 & 0.49 & 0.54 & 1.00 & & \\
\hline $\mathrm{As}$ & 0.25 & 0.91 & 0.93 & 0.84 & 0.69 & 1.00 & - \\
\hline $\mathrm{Md}$ & -0.51 & -0.88 & -0.80 & -0.93 & -0.65 & -0.87 & 1.00 \\
\hline
\end{tabular}

flat at these times are higher. The sedimentation rate on the tidal flats increased notably from the 1990s to 2012 at most of the core locations in the center and south of the study area (MC 4-MC 11), although the total water volume from rivers of the Red River and Thai Binh River systems only changed seasonally, not yearly. After completion of the Ho a Binh Dam, sediment flux was reduced quickly during the rainy season and the TSS were distributed near the shore, causing an increased sedimentation rate in the tidal flats from the center to the south of the study area. Sedimentation rates in the north of the study area (MC 2 and MC 3) increased slowly during 1887-2012 and were controlled by the small rivers with a sediment flux 9-10 times lower than the sediment flux in the center and south of the study area.

The high and increasingly heavy metal concentrations in the tidal flat sediments with time are related to increased socio-economic development in the region. The industrial areas in northern Vietnam are the second largest in Vietnam, with 31 areas in 2009. Only $25 \%$ of the wastewater from industrial areas is treated; the remaining $75 \%$ is untreated, which is contrary to the Vietnamese Standard Quality of Water [12-13]. A high concentration of heavy metals in sediments in the center to south were caused by sources from mainland dispersed not far by sediment flux reduce during 1990-2012, in addition to increasing industrial value every year in coastal provinces, neap tide time last longer than spring tide time in the south area so impact from rivers is higher than the sea in coastal areas, whereby heavy metals accumulated with the sedimentation rates in the tidal flats.

The $\mathrm{I}_{\mathrm{Geo}}$ of heavy metals (As, $\mathrm{Cd}, \mathrm{Pb}$ ) is high from center to south of the study area (MC 5 - MC 10) (Table 3), and they are low in the north of study area (MC 1 - MC 3). The EF indexes are high from MC 5 to MC 10 with ranges from 1.3-15.0, ranging from minor to very severe enrichment. These cores MC 5 - MC 10 with high $\mathrm{EF}$ indexes overlap with center developing industries area in Hai Phong, Thai Binh, and Nam Dinh provinces.

Using multivariate analyses with Origin Pro 9.1 (OriginLab) of $\mathrm{Md}$ and metals, the levels of heavy metals in tidal flat sediments depend on grain size, and fine sediments have high concentrations of heavy metals at MC 5 - MC 11, while low concentrations of heavy metals were found at MC $1-$ MC 3 with coarse sediments. The correlation, principal component analysis (PCA) have shown that: A negative correlation was found between heavy metal concentration and $\mathrm{Md}$ (Table 4), and a positive correlation was found between the concentrations of the different metals. The PCA results showed that principle component 1 (PC 1) is $73.10 \%$, indicating that the environment is controlled by $\mathrm{Cu}, \mathrm{Pb}, \mathrm{As}, \mathrm{Zn}$, and $\mathrm{Md}$; principle component 2 (PC 2) is $15.82 \%$, showing that the environment is affected by Al (Table 5, Fig. 7). In terms of sediment quality, three

Table 5. Eigenvalues of the correlation matrix and extracted eigenvectors.

\begin{tabular}{|c|c|c|c|c|c|c|c|}
\hline No. & Eigenvalue & $\begin{array}{c}\text { Percentage of } \\
\text { Variance (\%) }\end{array}$ & $\begin{array}{c}\text { Cumulative } \\
(\%)\end{array}$ & No. & Parameter & $\begin{array}{c}\text { Coefficients of } \\
\text { PC1 }\end{array}$ & $\begin{array}{c}\text { Coefficients of } \\
\text { PC2 }\end{array}$ \\
\hline 1 & 5.11691 & 73.10 & 73.10 & 1 & $\mathrm{Al}$ & 0.20 & 0.80 \\
\hline 2 & 1.10764 & 15.82 & 88.92 & 2 & $\mathrm{Cu}$ & 0.41 & -0.34 \\
\hline 3 & 0.54310 & 7.76 & 96.68 & 3 & $\mathrm{~Pb}$ & 0.41 & -0.27 \\
\hline 4 & 0.15123 & 2.16 & 98.84 & 4 & $\mathrm{Zn}$ & 0.42 & 0.02 \\
\hline 5 & 0.05721 & 0.82 & 99.66 & 5 & $\mathrm{Cd}$ & 0.31 & 0.37 \\
\hline 6 & 0.02337 & 0.33 & 99.99 & 6 & $\mathrm{As}$ & 0.42 & -0.17 \\
\hline 7 & $5.34 \times 10^{-4}$ & 0.01 & 100.00 & 7 & $\mathrm{Md}$ & -0.42 & -0.08 \\
\hline
\end{tabular}




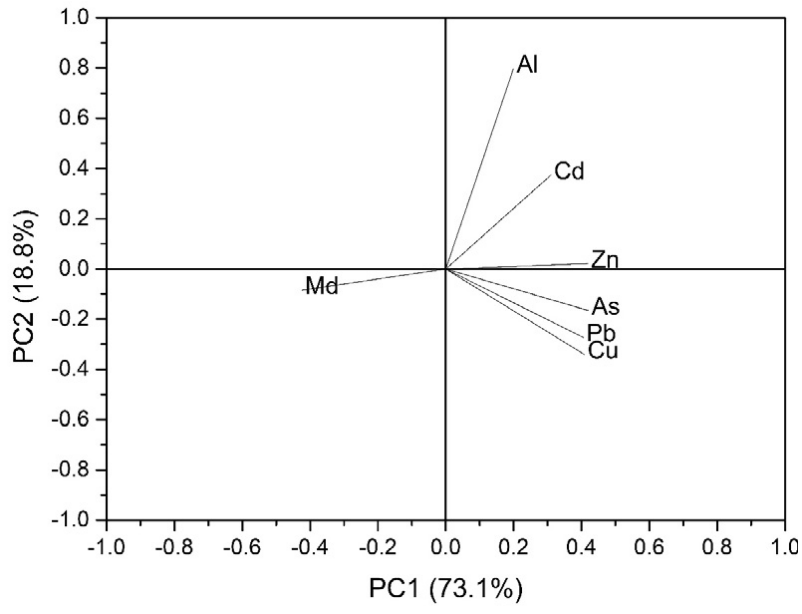

Fig. 7. Principal component analysis of sediment parameters.

of the five heavy metals $(\mathrm{Cu}, \mathrm{Pb}$, and $\mathrm{As})$, exceeded ISQG levels at six of nine positions, and $\mathrm{Cd}$ exceeded ISQG level in MC 5, but none of the metals were over the PEL levels [6].

When comparing sedimentation rates (Table 6) in this study with other areas, Tue N.T. et al. [1] calculated sedimentation rate in the $\mathrm{Ba}$ Lat River mouth in southern north Vietnam by constant initial concentration model (CIC) ranging $0.78-1.20 \mathrm{~cm} /$ year, Tue N.T.'s area close with positions of MC $8(0.77 \pm 0.83 \mathrm{~cm} /$ year $)$ - MC 9 cores $(3.04 \pm 5.27 \mathrm{~cm} /$ year $)$, the differences in sedimentation rate results caused by different positions and different model calculation. With coastal lagoons in the centre of Vietnam [14], sedimentation rate is two times lower than this study. With Lianyungang-China [15], sedimentation rate is higher in this study; Masan Bay, Korea [16]; Karnaphuli River, Bangladesh [17]; and Qinjiang River, China [18] are lower than this study.

In comparison, heavy metals (Table 6) with the previous studies of Tue N.T. et al. [1] had carried out in the south of area is not much different in results, with concentrations of $\mathrm{Cu}, \mathrm{Pb}, \mathrm{Zn}$ and $\mathrm{Cd}$ higher than those heavy metals in MC 8 core (this study). Higher concentrations of heavy metals are caused by different positions, and in addition Tue N.T.'s study carried our inside mangrove forest where fine sediments with $\mathrm{Md}<0.015 \mathrm{~mm}$ are common in the area, while this study (MC 8) is outside mangrove forest with $\mathrm{Md}>0.015 \mathrm{~mm}$ (MC 8 - Table 2). In the northern area, Ho H.H. et. al. [2] reported higher concentrations of $\mathrm{Cu}, \mathrm{Pb}, \mathrm{Zn}$ and As in comparison with MC 2 and MC 3 cores, where the area is close with some coal mining, coal screening factories and Cua Ong Harbour, so sediments are more impacted from these areas. With coastal lagoons in central Viet Nam [19], the concentration of heavy metals is lower than 1-2 times in this study. Other tidal flats in Lianyungang-China are higher than this study of $\mathrm{Pb}$, $\mathrm{Zn}, \mathrm{Cd}$, in Masan Bay, Korea [16], being higher than this study of Zn, the Karnaphuli River [17] and Qinjiang River [18] are lower than this study of $\mathrm{Cu}, \mathrm{Pb}, \mathrm{Zn}, \mathrm{As}$ and $\mathrm{Cd}$.

Table 6. Comparison of sediment features in the study area with other areas in the world.

\begin{tabular}{|c|c|c|c|c|c|c|c|}
\hline Places & $\begin{array}{c}\text { Sedimentation } \\
\text { rates } \\
(\mathrm{cm} / \text { year })\end{array}$ & $\begin{array}{c}\mathrm{Cu} \\
(\mathrm{mg} / \mathrm{kg})\end{array}$ & $\begin{array}{c}\mathrm{Pb} \\
(\mathrm{mg} / \mathrm{kg})\end{array}$ & $\begin{array}{c}\mathrm{Zn} \\
(\mathrm{mg} / \mathrm{kg})\end{array}$ & As $(\mathrm{mg} / \mathrm{kg})$ & $\begin{array}{c}\mathrm{Cd} \\
(\mathrm{mg} / \mathrm{kg})\end{array}$ & References \\
\hline $\begin{array}{c}\text { Tidal flat of the north } \\
\text { Vietnam }\end{array}$ & $\begin{array}{c}0.04-15.83 ; \\
(1.37)\end{array}$ & $\begin{array}{c}0.69-94.76 ; \\
(40.50)\end{array}$ & $\begin{array}{c}5.78-120.32 ; \\
(52.08)\end{array}$ & $\begin{array}{c}3.95-492.01 ; \\
(85.31)\end{array}$ & $\begin{array}{c}0.26-53.93 ; \\
(18.73)\end{array}$ & $\begin{array}{c}0.02-2.56 ; \\
(0.44)\end{array}$ & This study \\
\hline $\begin{array}{c}\text { Tidal flat of Red River } \\
\text { (in the south of this } \\
\text { area) }\end{array}$ & $\begin{array}{c}0.78-1.20 ; \\
(0.99)\end{array}$ & $\begin{array}{c}31.79-93.07 ; \\
(69.62)\end{array}$ & $\begin{array}{c}52.95-105.12 ; \\
(82.95)\end{array}$ & $\begin{array}{c}79.85-164.47 ; \\
(136.47)\end{array}$ & - & $\begin{array}{c}0.12-0.63 ; \\
(0.35)\end{array}$ & {$[1]$} \\
\hline $\begin{array}{c}\text { Cua Ong, Ha Long, } \\
\text { Vietnam (in the north } \\
\text { of this area) }\end{array}$ & - & $\begin{array}{c}13.00-30.00 ; \\
(20.00)\end{array}$ & $\begin{array}{c}4.00-41.00 ; \\
(16.00)\end{array}$ & $\begin{array}{c}12.00-94.00 ; \\
(40.00)\end{array}$ & $\begin{array}{c}13.00-62.00 ; \\
(26.00)\end{array}$ & $\begin{array}{c}0.02-0.20 ; \\
(0.09)\end{array}$ & {$[2]$} \\
\hline $\begin{array}{c}\text { Coastal lagoon in } \\
\text { centre of Vietnam }\end{array}$ & $\begin{array}{c}0.08-3.44 ; \\
(0.42)\end{array}$ & $\begin{array}{c}3.52-32.10 ; \\
(14.55)\end{array}$ & $\begin{array}{c}7.20-48.20 ; \\
(19.16)\end{array}$ & $\begin{array}{c}17.50-120.40 ; \\
(55.18)\end{array}$ & $\begin{array}{c}1.20-22.80 ; \\
(9.82)\end{array}$ & $\begin{array}{c}0.01-0.25 ; \\
(0.06)\end{array}$ & {$[14 ; 19]$} \\
\hline $\begin{array}{c}\text { The tidal flat of } \\
\text { Lianyungang, China }\end{array}$ & $\begin{array}{c}0.85-2.50 ; \\
(1.46)\end{array}$ & $\begin{array}{c}23.17-51.07 \\
(31.90)\end{array}$ & $\begin{array}{c}32.90-118.82 ; \\
(54.23)\end{array}$ & $\begin{array}{c}224.06-472.75 ; \\
(308.19)\end{array}$ & - & $\begin{array}{c}0.83-1.89 \\
(1.28)\end{array}$ & {$[15]$} \\
\hline The Masan Bay, & $0.28-0.44 ;$ \\
Korea & $\begin{array}{c}10.50-78.00 ; \\
(39.87)\end{array}$ & $\begin{array}{c}5.50-68.80 ; \\
(36.03)\end{array}$ & $\begin{array}{c}50.10-318.80 ; \\
(189.38)\end{array}$ & - & - & {$[16]$} \\
\hline $\begin{array}{c}\text { The Karnaphuli River } \\
\text { estuary, Chittagong, } \\
\text { Bangladesh }\end{array}$ & $\begin{array}{c}1.02-1.14 ; \\
(1.08)\end{array}$ & $\begin{array}{c}17.82-58.17 ; \\
(30.38)\end{array}$ & $\begin{array}{c}23.08-28.38 ; \\
(25.12)\end{array}$ & $\begin{array}{c}50.75-116.30 ; \\
(72.38)\end{array}$ & - & - & {$[17]$} \\
\hline $\begin{array}{c}\text { The tidal flats } \\
\text { of Qinjiang River } \\
\text { estuary, China }\end{array}$ & $\begin{array}{c}0.92-1.18 ; \\
(1.05)\end{array}$ & $\begin{array}{c}11.34-30.10 ; \\
(21.20)\end{array}$ & $\begin{array}{c}20.29-46.31 ; \\
(33.78)\end{array}$ & $\begin{array}{c}34.76-88.83 ; \\
(63.77)\end{array}$ & $\begin{array}{c}4.45-12.59 ; \\
(8.97)\end{array}$ & $\begin{array}{c}0.07-0.15 ; \\
(0.11)\end{array}$ & {$[18]$} \\
\hline
\end{tabular}

In-bracket is average value, out-bracket range from minimum to maximum 


\section{Conclusions}

On the tidal flat in northern Vietnam, the distribution of sediment ranges from coarse sediment $(\mathrm{Md}=0.130-0.224 \mathrm{~mm})$ to fine sediment $(\mathrm{Md}=0.015-0.075 \mathrm{~mm})$. Fine sediments are common in the center and the south of the study area, while coarse sediment is dominant in the north of the study area. Sedimentation rates on the tidal flats are from 0.04 to $15.00 \mathrm{~cm} /$ year, with an average of $0.14-0.87 \mathrm{~cm} /$ year in the north, 1.40-2.94 $\mathrm{cm} /$ year in the center, and 0.5-3.04 $\mathrm{cm} /$ year in the south. Sedimentation rates on the tidal flats reflect the impacts of human activities in the center from 1982 to 1985 , and of natural processes in the south in 1971, 1986, 2006, 2008, and 2010.

High concentrations of the heavy metals $\mathrm{Cu}, \mathrm{Pb}$, As, and $\mathrm{Cd}$ were found in the center and the south of the study area, exceeding ISQG levels, but none of the heavy metals had average concentrations over the PEL levels. The $\mathrm{I}_{\mathrm{Geo}}$ of the heavy metals show that the center and south of the study area are moderately to strongly polluted environments, and EF of heavy metals with moderate to severe enrichment. The $\mathrm{I}_{\mathrm{Geo}}$ and $\mathrm{EF}$ for the north of the study area indicate that it is an unpolluted to moderately polluted environment with no enrichment to minor enrichment. The high concentration of heavy metals found in the tidal flat sediments is related to industrial development in the hinterland.

\section{Acknowledgements}

This work was made possible with support from the project "Research to develop marine spatial planning in the Gulf of Tonkin," with code KC.09.16/16-20. We thank the Ministry of Sciences and Technology, Vietnam for funding this project. We also thank anonymous reviewers who provided helpful feedback to improve our work.

\section{Conflict of Interest}

The authors declare no conflict of interest.

\section{References}

1. TUE N.T., QUY T.D., AMANO A., HAMAOKA H., TANABE S., NHUAN M.T., OMORI K. Historical profiles of trace element concentrations in mangrove sediment from Ba Lat Estuary, Red River, Vietnam. Water Air Soil Pollution, 223 (3), 1315, 2012.

2. HO H.H, SWENNEN R., DAMME A.V. Distribution and contamination status of heavy metals in estuaine sediments near Cua Ong harbor, Ha Long bay, Vietnam. Geologica Belgica, 13 (1-2), 37, 2010.

3. VU D.V., OUILLON S., TRAN D.T., LA V.C. Impact of the Hoa Binh Dam (Vietnam) on water and sediment budgets in the Red River basin and delta. Hydrol. Earth
Syst. Sci. Discuss., 18 (10), 3987, 2014.

4. NHON D.H. Sedimentary environment evolution of intertidal zone in the North of Vietnam. PhD thesis, Hanoi University of Science, pp.1-142, 2015 [In Vietnamese].

5. LISITZIN A.P. Principles of geological mapping of marine sediments. Unesco Reports in Marine Science. 33, 1, 1986.

6. CANADIAN COUNCIL OF MINISTER OF THE ENVIRONMENT. Canadian environmental quality guidelines, update 2002.

7. MULLER G. Schwermetalle in den sediment des Rheins: Veranderungem Seit 1971. Umschau. 79, 778, 1979.

8. ERGIN M., SAYDAM C., BASTURK Ö., ERDEM E., YORUK R. Heavy metal concentrations in surface sediments from the two coastal inlets (Golden Horn Estuary and İzmit Bay) of the northeastern Sea of Marmara. Chemical Geology, 91 (1), 269, 1991.

9. RUDNICK R.L., GAO S. Composition of the continental crust. In the Treatise on Geochemistry, $2^{\text {nd }}$ ed.; Rudnick R.L., Elsevier: Amsterdam, The Netherlands, Volume 4, pp. 1,2014

10. NHON D.H., CHIEN H.T, ANH N.K., VUONG B.V., ANH N.N., AN P.H., HUNG V.M., HAI P.S. Sedimentation in Bang La and Ngoc Hai intertidal zone, Hai Phong. Journal of Marine Science and Technology, 11 (1), 1, 2011 [In Vietnamese].

11. Floods the North of Vietnam. Available online: https:// vi.wikipedia.org/wiki/C\%C3\%A1c_tr\%E1\%BA\%A Dn $1 \%$ C $5 \%$ A $91 \%$ E $1 \%$ BB $\%$ A 5 t $1 \%$ E $1 \%$ BB $\% 9 B n$ $\%$ E1\%BB\%9F_H\%C3\%A0_N\%E1\%BB\%99i_v\% $\% \mathrm{~A} 0 \_\mathrm{mi} \% \mathrm{E} 1 \% \mathrm{BB} \% 81 \mathrm{n} \_\mathrm{B} \% \mathrm{E} 1 \% \mathrm{BA} \% \mathrm{AFc} . \mathbf{2 0 1 6}$ [In Vietnamese].

12. CHUNG C.V. Environmental remediation work at industrial and export processing zones of Vietnam: Status and solution. Industrial Review of Vietnam. 4, 18, 2009 [In Vietnamese].

13. MINISTRY OF NATURAL RESOURCE AND ENVIRONMENT VIETNAM (MORE). Environmental Report of Vietnam: Environment of Industrial Zone. 2009 [In Vietnamese].

14. NHON D.H., ANH N.N., KHANG N.D., VUONG B.V., QUAN N.V., HAI P.S. Sedimentation in Coastal Lagoons: Tam Giang-Cau Hai, Thi Nai and Nai in the Centre of Vietnam. VNU Journal of Science: The Earth and Environment, 31 (3), 15, 2015 [In Vietnamese].

15. ZHANG R., ZHANG F., DING Y., GAO J., CHEN J., ZHOU L. Historical trends in the anthropogenic heavy metal levels in the tidal flat sediments of Lianyungang, China. Journal of Environmental Sciences, 25 (7), 1458, 2013.

16. CHO J., HYUN S., HAN J.H., KIM S., SHIN D.H. Historical trend in heavy metal pollution in core sediments from the Masan Bay, Korea. Marine Pollution Bulletin, 95 (1), 427, 2015.

17. WANG A.J., KAWSER A., XU Y.H., YE X., RANI S., CHEN K.L. Heavy metal accumulation during the last 30 years in the Karnaphuli River estuary, Chittagong, Bangladesh. Springer Plus, 5 (1), 2079, 2016.

18. XIA P., MENG X., FENG A., YIN P., WANG X., ZHANG J. ${ }^{210} \mathrm{~Pb}$ chronology and trace metal geochemistry in the intertidal sediment of Qinjiang River estuary. China, J. Ocean Univ. China, 11 (2), 165, 2012.

19. STEFANIA R., CRISTIAN M., SILVIA G., CLARA T., CU N.H., LUCA G.B., NHON D.H., GABRIELE C., MAURO F. Metals in Sediment Cores from Nine Coastal Lagoons in Central Vietnam. American Journal of Environmental Sciences, 8 (2), 130, 2012. 